\title{
KANTOR UNTUK MILENIAL
}

\author{
Albert Satyagraha ${ }^{1)}$, Budi Adelar Sukada ${ }^{2)}$ \\ 1)Program Studi S1 Arsitektur, Fakultas Teknik, Universitas Tarumanagara, dionisiusalbert@gmail.com \\ 2) Program Studi S1 Arsitektur, Fakultas Teknik, Universitas Tarumanagara, budisukada@yahoo.com
}

\begin{abstract}
Abstrak
Generasi millennial adalah generasi kelahiran sekitar tahun 1980 sampai dengan 2000, dimana pada saat ini berumur 20 sampai 39 tahun. Saat ini generasi millenial mengisi angkatan terbesar kedua di Indonesia, yaitu sebesar $40 \%$ dan akan terus bertambah ke depannya. Millennial adalah kaum yang mudah bosan dalam melakukan suatu hal, mereka senang pindah-pindah kerja. Rata-rata millennial pindah kerja hingga 4 kali dalam 10 tahun. Hal ini merupakan akibat dari lingkungan kerja yang tidak sesuai dengan yang mereka inginkan. Mereka tidak menyukai lingkungan kerja yang formal dan kaku, dimana mereka harus menghabiskan waktu bekerja dengan duduk di depan komputer selama berjam-jam dengan waktu yang sudah ditentukan. Millenial menyukai kebebasan dalam melakukan sesuatu. Mereka akan berusaha membuat diri mereka senyaman mungkin dalam bekerja tanpa terikat tempat dan waktu. Selain itu, pengaruh lain yang membuat mereka tidak nyaman dalam tempat kerjanya adalah pekerjaan yang dilakukan itu-itu saja, tanpa adanya hal dan tantangan baru. Dalam menghadapi masalah yang ada, kita perlu mempelajari seperti apa karakteristik millenial terlebih dahulu, lalu menyesuaikan dengan sistem dan lingkungan kerja yang mereka butuhkan. Millenial membutuhkan wadah untuk mereka bekerja, yang dapat membuat mereka merasa nyaman dan tidak merasa tertekan. Hal ini akan membuat mereka merasa kerja bukanlah suatu tuntutan dan hukuman, melainkan bagian dari hidup yang dijalaninya.
\end{abstract}

Kata kunci: Fleksibilitas; Kenyamanan; Kerja; Kreativitas; Lingkungan

\begin{abstract}
Millennial generation is the generation of births from 1980 to 2000, which is currently 20 to 39 years old. Currently the millennial generation fills the second largest generation in Indonesia, which is $40 \%$ and will continue to grow in the future. Millennials are people who are easily bored in doing things, they like to move around. The average millennial has moved to 4 times in 10 years. This is a result of a work environment that does not match what they want. They do not like a formal and rigid work environment, where they have to spend time working by sitting at the computer for hours with a set amount of time. Millennials love the freedom to do things. They will try to make themselves as comfortable as possible in work without being bound by time and place. In addition, other influences that make them uncomfortable in their workplaces are the work done just that, without new things and challenges. In dealing with existing problems, we need to learn what millennial characteristics are like, then adjust to the system and work environment they need. Millennials need containers for them to work, which can make them feel comfortable and not feel depressed. This will make them feel work is not a demand and punishment, but a part of the life they live.
\end{abstract}

Keywords: Creativity Environment; Convenience; Flexibility; Work 


\section{PENDAHULUAN}

Generasi millennial segera menjadi angkatan kerja terbesar di Indonesia. Berdasarkan data BPS di tahun 2016, dari total jumlah angkatan kerja di Indonesia yang mencapai 160 juta, hampir $40 \%$ di antaranya tergolong millennial-sebesar 62,5 juta. Terbanyak kedua setelah generasi $X$ yang mencapai 69 juta, dan jauh di atas generasi Baby Boomers yang hanya tersisa 28,7 juta.

Millennial adalah kaum yang senang pindah-pindah kerja. Rata-rata millennial pindah kerja hingga 4 kali dalam 10 tahun. Hal ini merupakan akibat dari lingkungan kerja yang tidak sesuai dengan yang mereka inginkan. Mereka tidak menyukai lingkungan kerja yang formal, dimana mereka harus menghabiskan waktu bekerja dengan duduk di depan komputer selama berjamjam dengan waktu yang sudah ditentukan. Millenial menyukai kebebasan dalam melakukan sesuatu. Mereka akan berusaha membuat diri mereka senyaman mungkin dalam bekerja tanpa terikat tempat dan waktu. Oleh karena itu unit kerja yang beragam dan lengkapnya fasilitas dalam lingkungan kerja, dapat membuat mereka merasa lebih nyaman dan menikmati pekerjaan itu, sehingga dari beberapa faktor yang ada, dapat tercipta suatu keseimbangan kerja.

Selain faktor teknis di lingkungan tempat kerja, kaum millennial rentan berpindah kerja karena faktor psikis. Hal ini berkaitan dengan relasi mereka dalam suatu perusahaan terutama dengan atasan dan generasi sebelumnya. Generasi millennial adalah generasi yang sangat ingin dihargai, mereka menyukai belajar langsung dari generasi sebelumnya, namun tidak suka diremehkan. Mereka tidak segan untuk angkat kaki dari suatu perusahaan apabila hasil kerjanya atau posisinya dalam suatu perusahaan kurang dihargai.

Proyek dengan tema "Office for Millenials" ini bertujuan untuk berperan serta dalam menciptakan lingkungan kerja yang nyaman dan ramah terhadap kaum millenial. Untuk menjawab semua itu, kita harus mengenal terlebih dahulu seperti apa generasi millenial, lalu menyesuaikan dengan sistem yang lingkungan kerja yang mereka butuhkan. Dalam hal ini arsitektur harus mampu menyesuaikan diri dengan karakteristik millenial, bukan sebaliknya.

\section{KAJIAN LITERATUR}

\section{Generasi Millenial}

Generasi millennial atau sering disebut generasi $Y$ adalah kelompok generasi yang lahir diantara tahun 1980 dan 2000. Di tahun 2020, generasi millennial akan berada pada usia 2040 tahun, dimana merupakan usia yang produktif Indonesia (Ali : 2016). Terlepas dari itu generasi millennial merupakan penduduk dengan jumlah yang mendominasi di Indonesia.

\section{Definisi Kantor}

Kantor (dari bahasa Belanda kantoor) adalah sebutan untuk tempat yang digunakan untuk perniagaan atau perusahaan yang dijalankan secara rutin. Kantor bisa hanya berupa suatu kamar atau ruangan kecil maupun bangunan bertingkat tinggi. Kantor sering dibagi kepada dua jenis; kantor yang terbesar dan terpenting biasanya dijadikan kantor pusat, sedangkan kantorkantor lainnya dinamakan kantor cabang.

\section{Sejarah Kantor}

Kantor komersial pertama muncul di kota-kota industri Utara di Amerika Serikat pada akhir abad ke 19. Dengan ditemukannya telegraf dan telepon, kantor bisa berada jauh dari tempat tinggal dan pabrik dengan proses produksi dan distribusi yang tetap terkontrol. Beberapa teknologi baru pada saat itu seperti penerangan dengan sumber daya listrik, mesin tik dan alat hitung membuat informasi mudah didapat dan diproses lebih cepat dan akurat daripada sebelumnya.

Perkembangan teknologi dikatakan berkembang pesat pada saat itu. Pusat jaringan kereta api Amerika yang berada di Chicago, menerapkan teknologi berupa rangka baja dan lift pada gedung kantor. Hal ini menyebabkan kantor dapat dibangun lebih tinggi dari sebelumnya, 
sehingga keuntungan yang dihasilkan pada sebuah lahan lebih maksimal. Ini adalah kantor pertama yang menggunakan tata ruang tradisional, dimana tiap ruang dipisahkan oleh pembatas ruang dan pintu masuk ke setiap ruangan menghadap koridor.

Denah ini dibuat tipikal dan disusun secara vertikal untuk menghasilkan keuntungan lebih besar lagi dari sebuah lahan. Pemikiran seperti ini mulai diterapkan pada gedung-gedung kantor di Chicago dan New York pada awal abad ke 20.

\section{Tipe Unit Kantor}

1. Traditional Office (cellular rooms)

Dalam satu lantai terdapat pembatas ruang berupa tembok permanen yang membentuk unit-unit kecil di dalamnya. Besar kecilnya luasan disesuaikan dengan keinginan pemilik kantor. Di setiap sudut ruang biasa diletakkan jendela untuk pencahayaan alami.

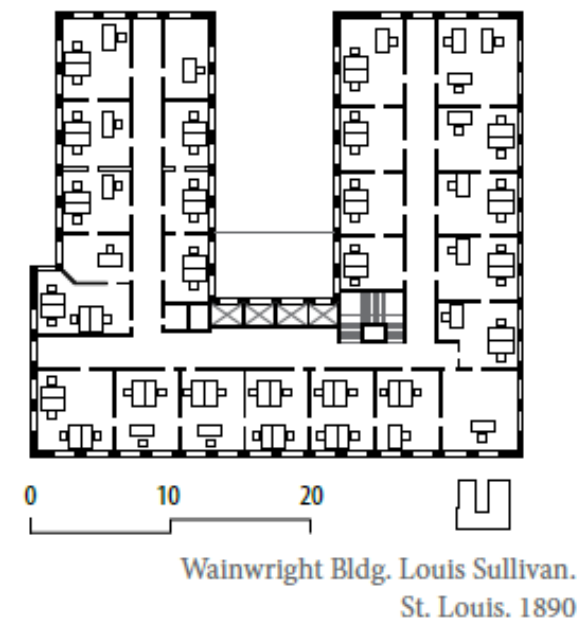

Gambar 2. Tipologi Kantor Tradisional Sumber: Anton, 2015

- Kelebihan tipe traditional office : meningkatkan privasi, konsentrasi pekerja meningkat

- Kekurangan tipe traditional office : hierarki ruang kaku, fleksibilitas rendah, sistem kolaborasi kurang

\section{Taylorist Open Plan}

Tipe ini banyak digunakan pada awal abad ke 19. Pada tipe ini, meja kerja disusun dalam beberapa barisan pada satu ruang besar tanpa sekat. Tipe seperti ini biasa digunakan untuk perusahaan mail-order, asuransi perusahaan dan agen pemerintahan.

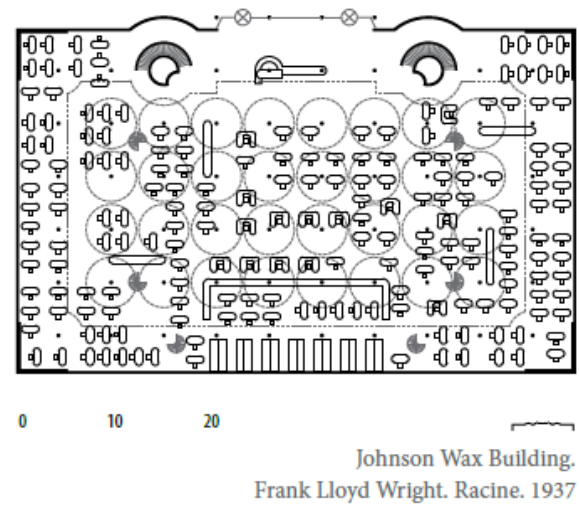

Gambar 3. Tipologi Kantor Open Plan Sumber: Anton, 2015 
- Kelebihan tipe taylorist open plan: meningkatkan sistem kolaborasi, biaya murah, ruang multifungsi.

- Kekurangan tipe taylorist open plan: hierarki ruang kaku, kebisingan meningkat, kurangnya privasi.

\section{Burolandschaft}

Ide layout dengan bentuk radikal ini ditemukan oleh Jerman pada tahun 1950. Tipe dengan nama lain lanskap kantor ini memiliki layout yang didasarkan pada studi intensif pola komunikasi.
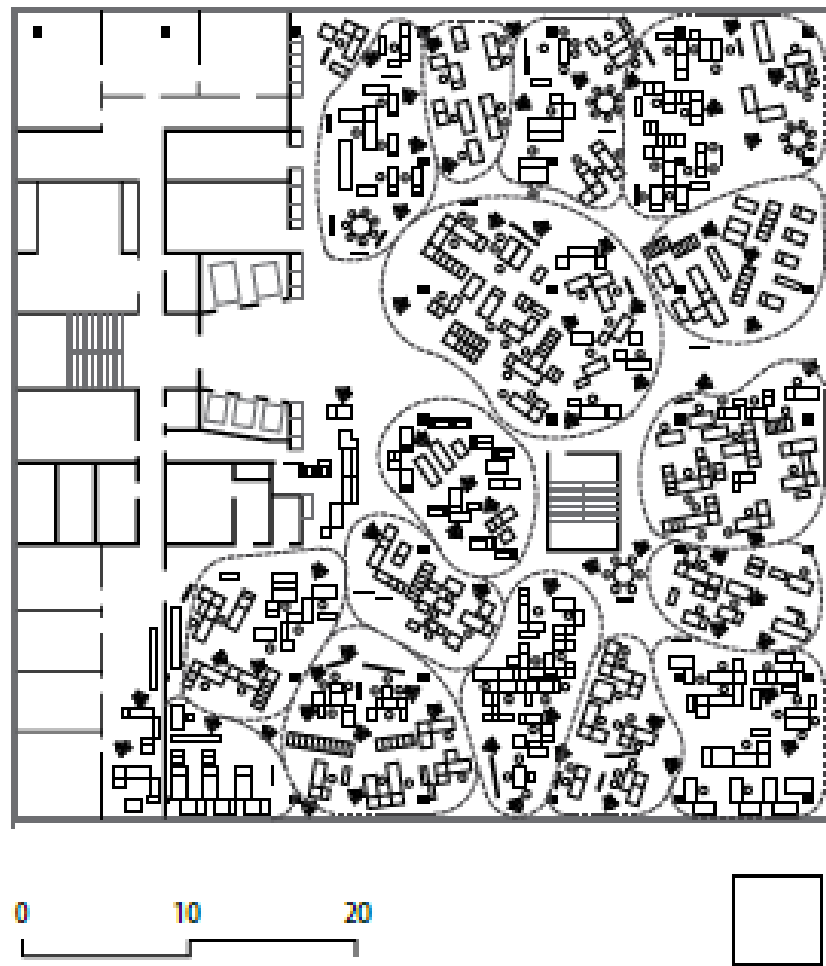

\section{Osram Offices. Quickborner. Munich. 1963}

Gambar 4. Tipologi Kantor Burolandschaft Sumber: Anton, 2015

- Kelebihan tipe burolandschaft : lingkungan non-hirarkis yang meningkatkan komunikasi dan kolaborasi.

- Kekurangan tipe burolandschaft : kebisingan meningkat, kurangnya privasi.

\section{Structuralist Office}

Tipe ini pertama diterapkan pada bangunan perusahaan Central Beheer di Apeldoorn, Belanda. Tipe yang dikembangkan oleh Herman Herzberger ini terdiri dari unit-unit kecil yang disusun dan terkoneksi satu dengan yang lain menyerupai lego atau susunan puzzle. Konsep dari tipe bangunan ini adalah menciptakan suatu desa pekerja dimana penghuni akan memiliki perasaan menjadi bagian dari komunitas yang bekerja tanpa tersesat di tengah keramaian. Pada perusahaan ini pekerja diberi kebebasan, seperti boleh membawa furniture dan menghias ruang kerja yang mereka miliki, serta membawa anggota keluarga ke ruang kerjanya. 
Centraal Beheer, Herman Hertzberger,

Apeldoorn. 1970

Tabel 5. Tipologi Kantor Structuralist Sumber: Anton, 2015

- Kelebihan tipe structuralist office : meningkatkan komunikasi dan kolaborasi, lingkungan kerja menyerupai rumah, mempersonalisasikan tempat kerja.

- Kekurangan tipe structuralist office : layout menyerupai labirin membuat orang mudah tersesat.

\section{Cubicles}

Tipe cubicle ini merupakan tipe dengan ruang kerja tertutup sebagian. Dibatasi partisi dengan ketinggian 1,5-1,8 $\mathrm{m}$, tipe ini bertujuan mengisolasi pekerja dari lingkungan sekitar dan kebisingan sehingga mereka dapat berkonsentrasi tanpa gangguan. Kantor dengan tipe ini disebut juga lautan bilik atau pertanian kubus. Bilik kantor yang diciptakan oleh desainer Robert Propst pada tahun 1967 ini biasa banyak digunakan di perusahaan teknologi.

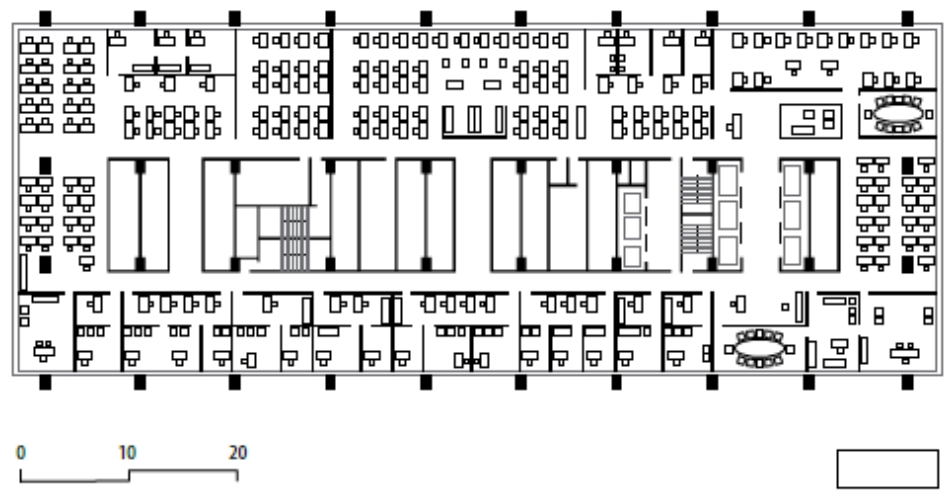

Chase Manhattan Bank, SOM, New York. 1961

Gambar 6. Tipologi Kantor Cubicle Sumber: Anton, 2015

- Kelebihan tipe cubicle : tingkat privasi relative.

- Kekurangan tipe cubicle : ruang kerja seragam sehingga memberi kesan monoton. 


\section{Euro Stakeholder Office}

Tipe ini menggabungkan tipe cellular office dengan ruang publik seperti kafe dan area relaksasi lainnya. Kantor dengan tipe ini mendominasi di Benua Eropa hingga saat ini.

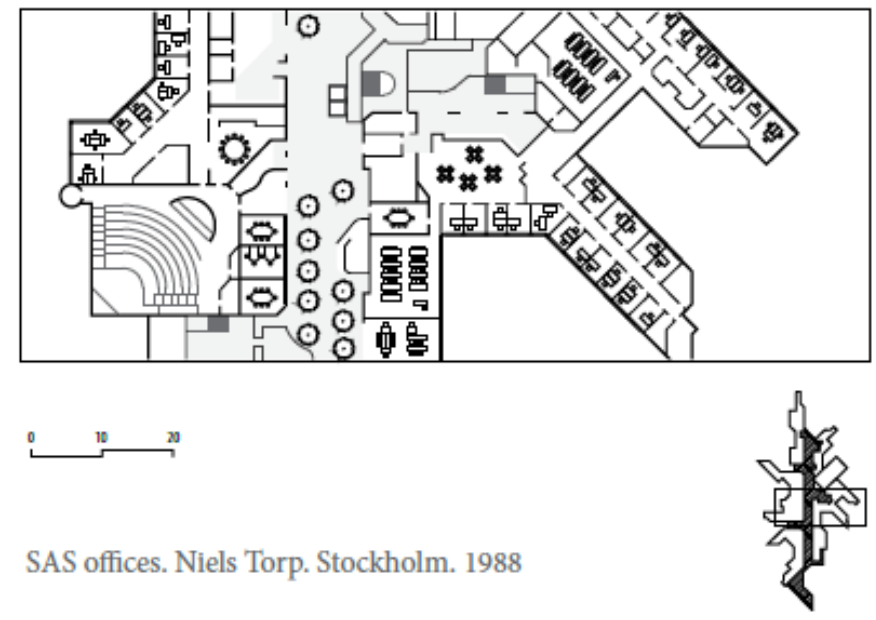

Gambar 7. Tipologi Kantor Stakeholder Sumber: Anton, 2015

- Kelebihan tipe Euro Stakeholder Office : meningkatan privasi, bangunan yang lebih berkelanjutan.

- Kekurangan tipe Euro Stakeholder Office : memberi kesan monoton apabila di tiap sisi kantor menggunakan tipe office cellular.

\section{Casual Office}

Kantor dengan tipe ini dipelopori oleh perusahaan perangkat lunak Silicon Valley di tahun $80 a n$, yang mendorong ruang kerja yang sangat personal dan cocok digunakan berjam-jam untuk bidang pemrograman. Kantor dengan tipe ini beroperasi selama 24 jam dengan waktu kerja yang fleksibel. Kantor dengan tipe ini banyak digunakan oleh perusahaan teknologi dan startup.

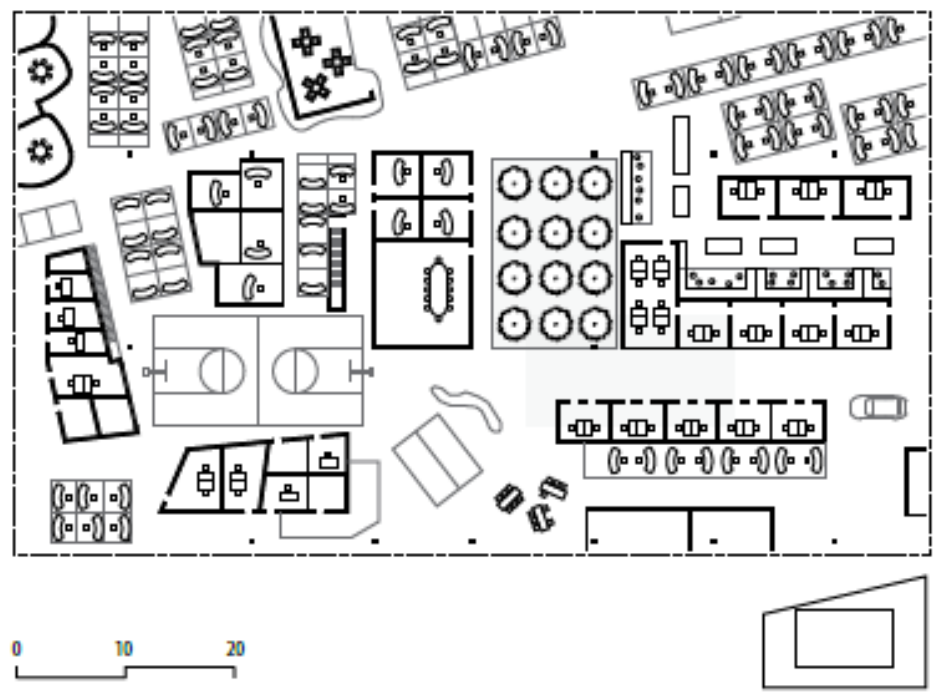

ChiatDay offices. Clive Wilkinson Architects. Los Angeles. 1997

Gambar 8. Tipologi Kantor Casual

Sumber: Anton, 2015 
- Kelebihan tipe Casual Office : ruang kerja berbasis aktivitas, lingkungan kerja yang fleksibel.

- Kekurangan tipe Casual Office : sulit untuk mengontrol pekerjaan karyawan.

8. Virtual Office

Meluasnya penggunaan Internet, laptop dan ponsel memiliki efek terbesar pada perkembangan kantor baru-baru ini. Kerja bisa menjadi lebih mobile dan pindah dari kantor ke kafe atau rumah. Tipe ini memberi fleksibilitas waktu dan tempat bagi pekerja. Tipe kantor dengan sistem hot-desking dan teleworking ini nantinya akan menggantikan kantor dengan sistem konvensional.

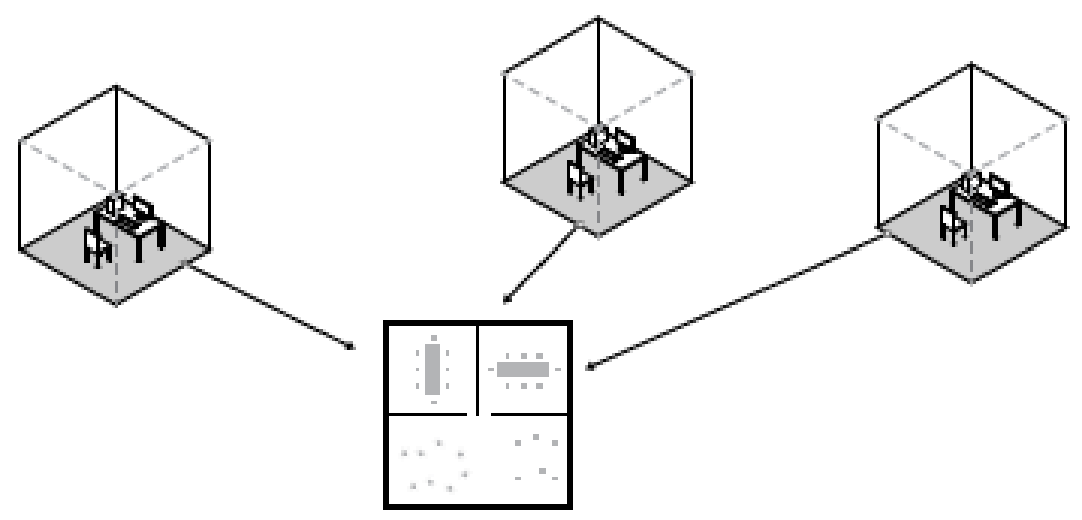

Gambar 9. Sistem Virtual Office

Sumber: Anton, 2015

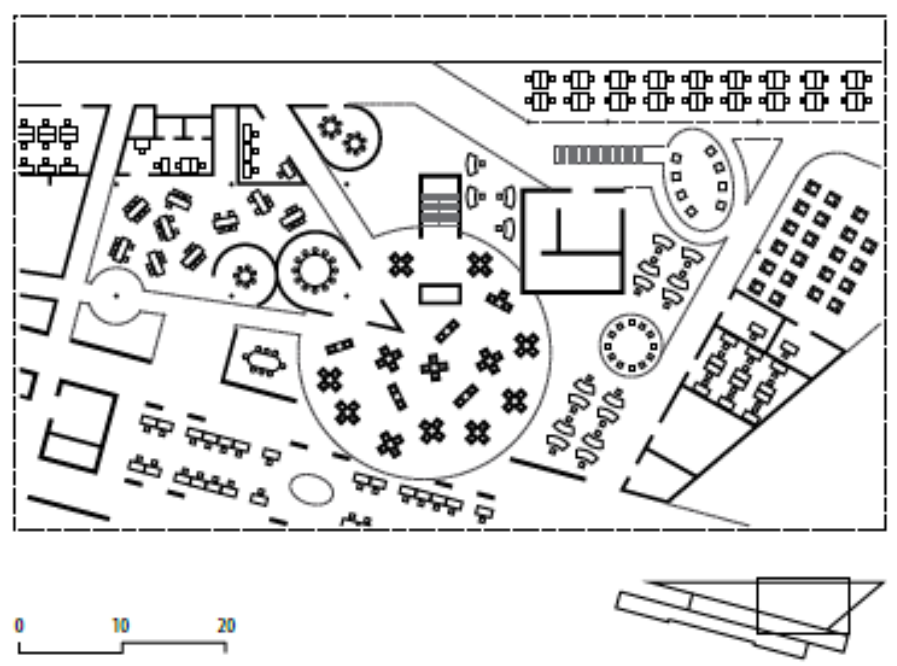

Interpolis HQ. Bonnema Architecten. Tilburg. 1995

Gambar 10. Tipologi Virtual Office

Sumber: Anton, 2015

- Kelebihan tipe Virtual Office : mengurangi biaya sewa, mengurangi waktu dan biaya transportasi.

- Kekurangan tipe Virtual Office : kurangnya interaksi, penurunan produktivitas. 


\section{METODE}

Perancangan ini menggunakan Activity Based Workplace (ABW) sebagai metodenya. Metode ini menjadikan aktivitas sebagai dasar dan pertimbangan dalam menciptakan suatu rancangan. ABW menyesuaikan pekerja dengan aktivitasnya, bukan menyesuaikan aktivitas dengan pekerjanya, sehingga fleksibilitas menjadi kunci dalam digunakannya metode ini.

Dari beberapa aspek yang diambil, dapat disimpulkan kapan, dimana dan seperti apa aktivitas yang akan dilakukan. Aspek waktu berkaitan dengan waktu operasional aktivitas, aspek tempat berkaitan dengan lokasi diadakannya aktivitas, sedangkan aspek cara kerja berkaitan dengan sistem yang digunakan dalam aktivitas. Masing-masing dari aspek tersebut diolah menjadi satu bentuk fisik yang biasa disebut ruang.

Hasil dari metode ini adalah munculnya beberapa program dan jenis unit kerja berdasarkan kebutuhan, yaitu:

- Individu

-Private workspace

-Open sharing workspace

-Closed sharing workspace

- Kelompok

-Open group workspace

-Closed group workspace

- Fasilitas pendukung

-Outdoor workspace

-Flexibility workspace

-Gym

-Canteen

-Communal Space

Dari beberapa program dan unit yang dibuat, para pekerja millenial dapat memilih sendiri lingkungan kerja yang mereka mau dan tentunya akan membuat mereka merasa nyaman dan leluasa dalam bekerja. Banyaknya opsi dalam bekerja juga membuat produktivitas mereka meningkat. Program dan unit kerja yang ada, dibuat berdasarkan beberapa jenis karakter millenial dalam melakukan suatu pekerjaan, baik dari segi cara mereka bekerja hingga kebutuhan atau fasilitas yang mereka butuhkan, baik itu saat bekerja maupun saat istirahat.

\section{DISKUSI DAN HASIL}

Dari isu millennial yang dibahas, program utama yang dipilih adalah kantor. Program kantor ini dipilih dengan tujuan mewadahi kaum millennial yang saat ini jumlahnya mencapai $40 \%$ dari total 160 juta angkatan kerja di Indonesia, dan akan terus bertambah dalam waktu dekat ini. Program ini juga akan menyelesaikan masalah millennial dengan dunia kerja dimana saat ini mereka sering berpindah-pindah kerja, karena tempat kerja yang tidak sesuai dengan keinginan dan kebutuhan mereka.

Bidang kerja yang diambil pada program ini adalah teknologi, lebih spesifiknya teknologi pada software dan peralatan elektronik. Teknologi adalah bidang yang terus berkembang dari jaman ke jaman, yang memerlukan kreativitas dan tantangan-tantangan baru dalam menyelesaikannya. Hal ini sangat sesuai dengan karakteristik kaum millennial, terlebih lagi mereka hidup pada masa dimana teknologi berkembang sangat pesat dan posisinya sudah menjadi bagian dalam kehidupan sehari-hari.

\section{Biophilic Design}

Biophilic berasal dari kata biophilia yang memiliki arti hubungan manusia dengan alam. Manusia hidup dalam sebuah lingkungan yang mampu mempengaruhi kondisi fisik maupun mentalnya. Selain itu aktivitas yang dilakukan oleh manusia sehari-hari juga menjadi sebuah 
kunci utama kondisi tubuhnya. Sadar atau tidak sadar faktor eksternal mempengaruhi kondisi mental manusia itu sendiri. Kondisi mental manusia akan menghasilkan sebuah respon yang salah satunya adalah emosi yang berkaitan erat dengan produktivitas.

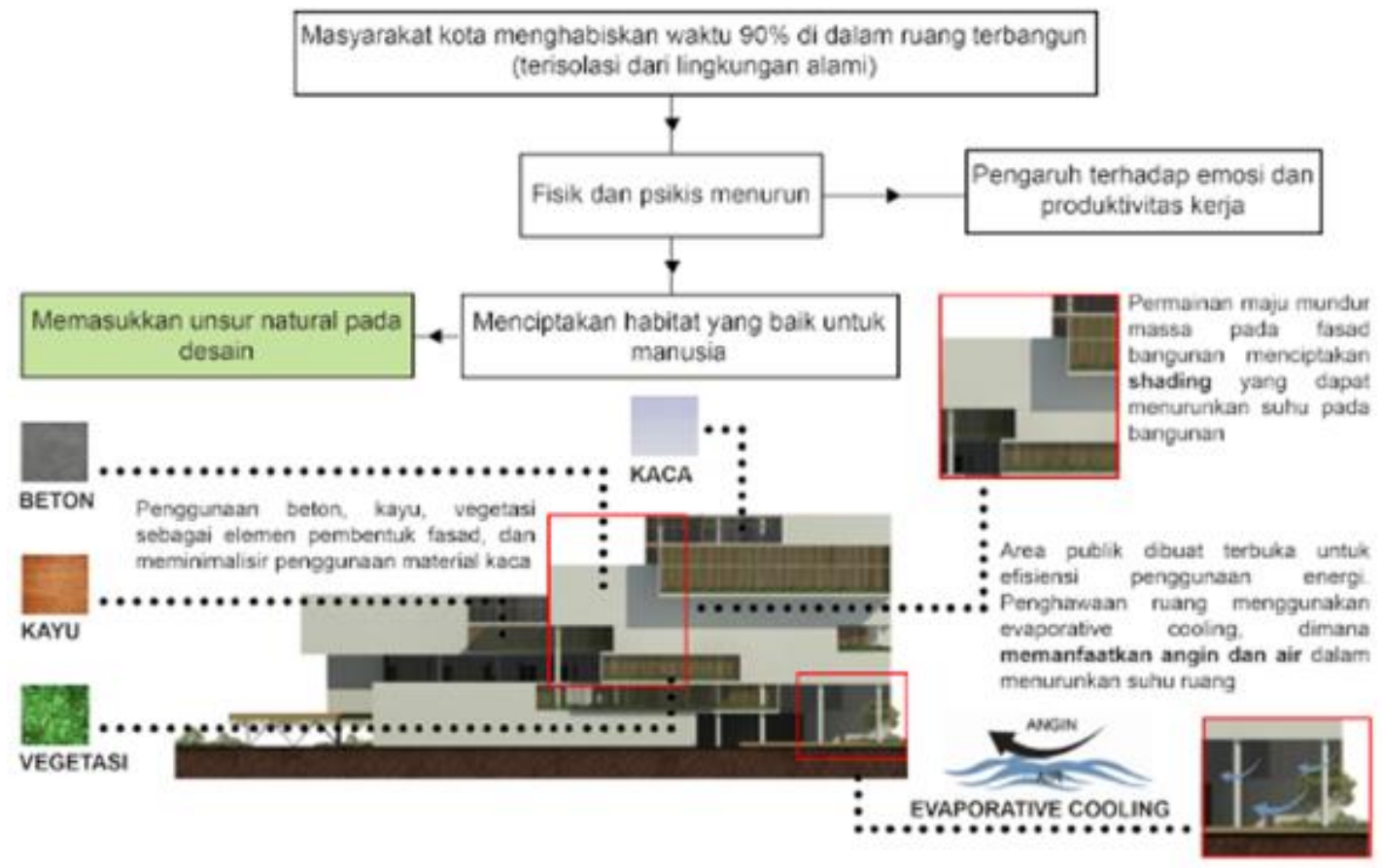

Gambar 12. Konsep Biophilic Sumber: Penulis, 2019

Tipologi Ruang Kerja
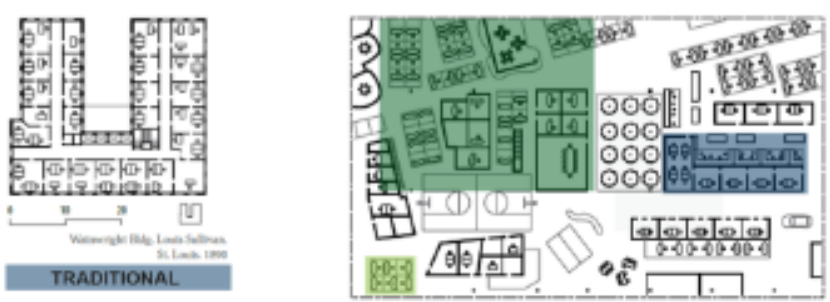

\section{CASUAL OFFICE}

Kantor dengan tipe ini dipelopori oleh perusahaar perangkat lunak Silicon Valey di tahun 1980, yang mendorong ruang kerja yang yang sangat personal dan cocok digunakan berjam-jam unflk bidang pernrograman. Kantor dengan tipe ini beropasi selama 24 jam dengan waktu kerja yang fleksibel. Kantor dengan tipe ini taryak digunakan oleh perusahaan teknologi dan startup Kelebihan:
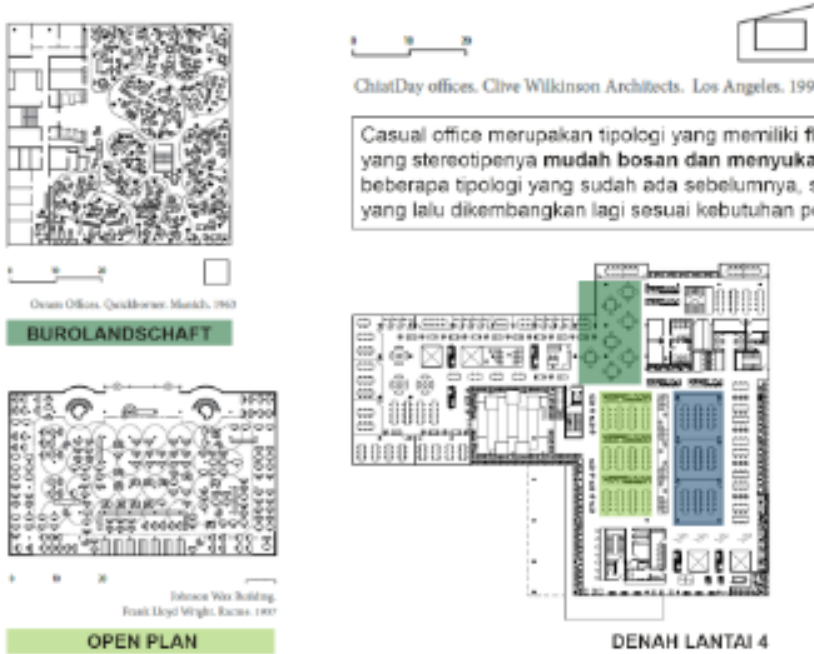

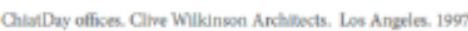

Ruang kerja berbasis aktivitas sehingga menjadi lebih fieksibel

Kekurangan:

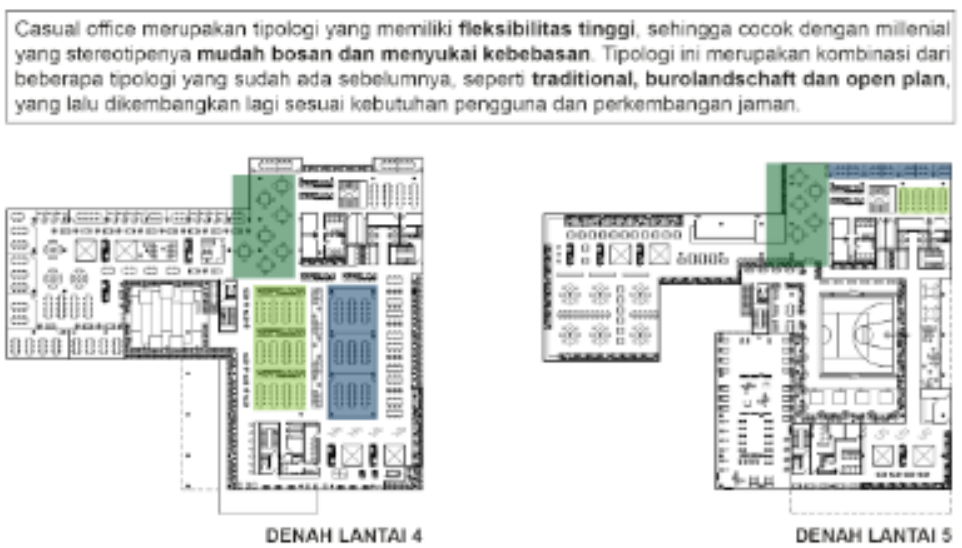

Gambar 13. Tipologi Ruang Sumber: Penulis, 2019 


\section{Sistem Kerja}

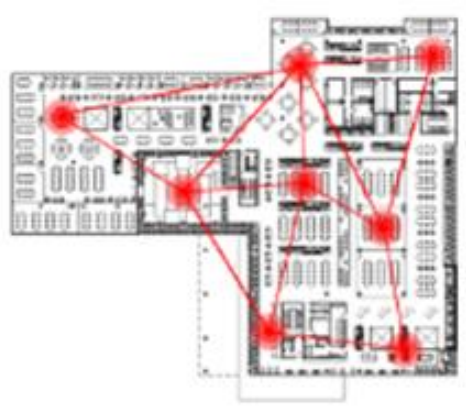

\section{Nomadic Workspace \\ Nomadic workspace membuat sistem kerja yang fleksibel. Pengguna tidak diharuskan berdiam diri dalam 1 tempat selama berjam-jam. melainkan mereka dapat memilih tempat dan suasana kerja yang mereka inginkan.}

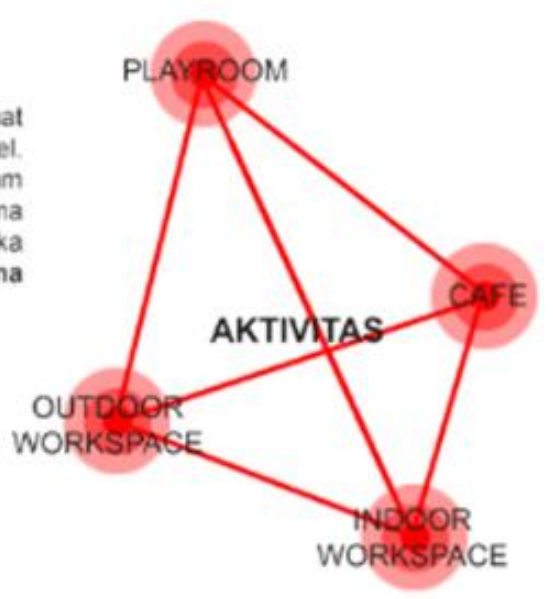

Gambar 14. Sistem Kerja

Sumber: Penulis, 2019

\section{Unit Kerja}

Unit kerja yang digunakan memiliki beberapa jenis, seperti ruang kerja tertutup dan terbuka, yang lalu dispesifikasikan lagi sesuai dengan jumlah dan kebutuhan penggunannya. Selain itu terdapat juga fasilitas seperti playroom dan pantry yang dapat digunakan di sela-sela kegiatan bekerja

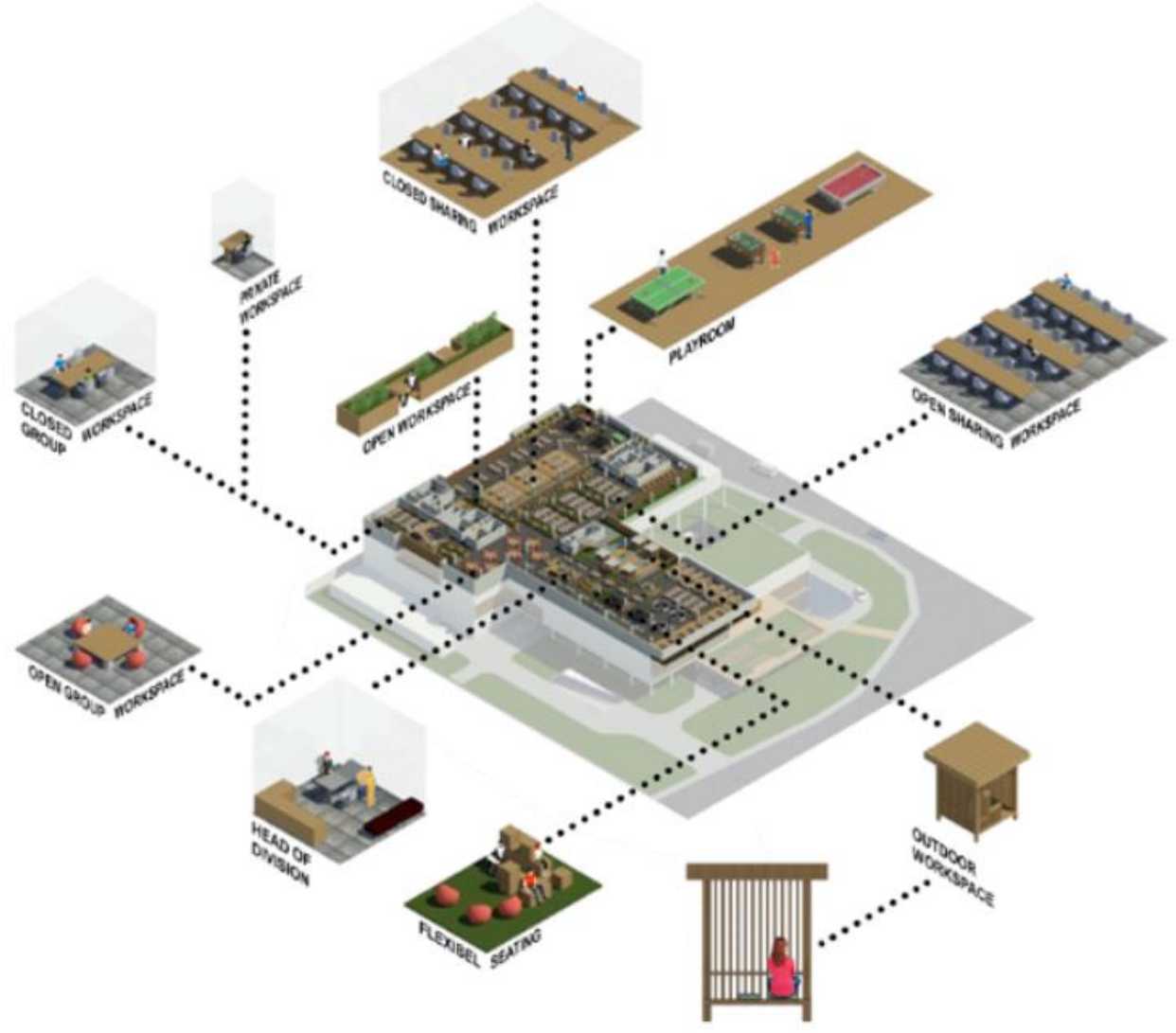

Gambar 15. Sistem Kerja

Sumber: Penulis, 2019 

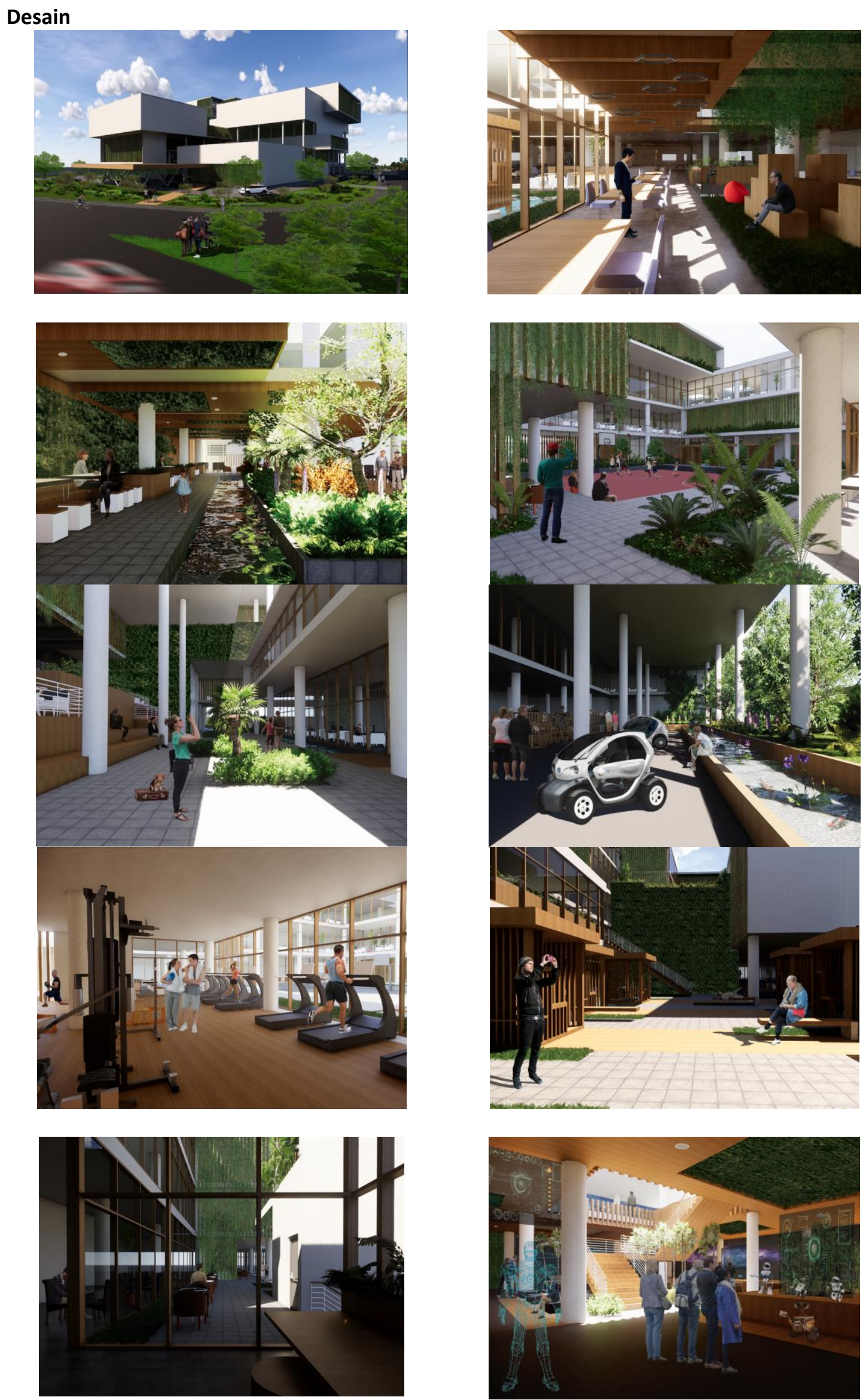

Gambar 16. Desain Eksterior dan Interior

Sumber: Penulis, 2019 


\section{KESIMPULAN DAN SARAN}

Program kantor ini dibuat untuk mewadahi kaum millenial yang saat ini mengisi $40 \%$ dari angkatan kerja di Indonesia. Karakteristik millenial yang mudah bosan dan senang berpindahpindah kerja, membuat program ini harus mampu beradaptasi dalam memahami apa yang millenial butuhkan dan inginkan. Program ini didukung dengan konsep biophilic, dimana konsep ini mampu meningkatkan produktivitas dan kesejahteraan pengguna yang ada di dalam lingkungan kerja. Selain itu, konsep biophilic ini menciptakan suatu lingkungan kerja yang unik, karena temanya yang berbeda dibandingkan lingkungan kerja pada umumnya

Penyesuaian tipologi dan sistem pada bangunan pun dilakukan untuk menjawabnya, hingga dapat diambil kesimpulan bahwa kantor dengan fleksibilitas tinggi seperti tipe casual office adalah yang paling sesuai dengan kaum millenial.

Proyek ini menggunakan Activity Based Workplace sebagai metode dalam merancang dan studi kasus sebagai pertimbangan kriteria dalam pemilihan tapak. Lokasi yang dekat dengan pemukiman, prasarana moda transportasi publik dan tempat hiburan menjadi alasan yang kuat apabila dikaitkan dengan tipikal millenial yang menyukai tempat kerja strategis dan mudah dijangkau. Lokasi yang strategis ini dapat dilihat dari letaknya yang mudah dijangkau dan sarana prasarana memadai, seperti jalan antar provinsi, terminal dan halte bus dengan jangkauan seluruh hingga luar jakarta, dan stasiun kereta dengan jangkauan Jabodetabek hingga beberapa kota di pulau Jawa.

Dapat disimpulkan bahwa disini arsitektur memiliki peran penting dalam menciptakan suatu lingkungan kerja yang nyaman, aman dan dibutuhkan kaum millenial. Arsitektur harus mampu menyesuaikan dan beradaptasi dengan karakteristik mereka, agar mereka betah berada di lingkungan kerjanya dan mampu memaksimalkan potensi yang mereka miliki.

\section{REFERENSI}

(2008). Retrieved from Archdaily: www.archdaily.com

Adam, A. (2017, Mei 14). Milenial Tua Versus Milenial Muda. Retrieved from Tirto.id: https://tirto.id/milenial-tua-versus-milenial-muda-coEL

Ali, H. (2016). Memahami Millenial Indonesia. Jakarta: Alvara Research Center.

Anton, K. (2015). History of the Office. Office, 4-11.

Bunga, R. (2018, Januari 11). Ini 5 Kriteria Kantor Idaman Para Generasi Millennial. Retrieved from idntimes.com: https://www.idntimes.com/life/career/rully-bunga/kriteria-kantoridaman-generasi-millennial/full

Day, N. (2019, Januari 13). The Three Classes of Office Buildings. Retrieved from The Balance

Small Bussiness: https://www.thebalancesmb.com/classes-of-office-buildings-2866557

Debora, Y. (2017, September 7). Ke Mana Mengalirnya Uang Para Milenial? Retrieved from Tirto,id: https://tirto.id/ke-mana-mengalirnya-uang-para-milenial-cv76

Finance, D. o. (2013, September). Flexible and Efficient Workplace Design Guidance. Retrieved from Australian Government Department of Finance: www.finance.gov.au

Francis Duffy, Colin Cave, John Worthington. (1985). Planning Office Space. New York: Nichols Publishing Company.

Garnesia, I. (2018, September 12). Sana-sini Ngaku Milenial, Bagaimana Peta Milenial Indonesia? Retrieved from Tirto.id: https://tirto.id/sana-sini-ngaku-milenial-bagaimanapeta-milenial-indonesia-cX5W

Google Earth. (n.d.). Retrieved from https://www.google.com/earth/

Google Images. (n.d.). Retrieved from https://images.google.com/

Google Maps. (n.d.). Retrieved from https://maps.google.com/

Google Street View. (n.d.). Retrieved from https://www.google.com/streetview/

hardi91. (2010, Maret 1). Pola-Pola Sirkulasi Ruang. Retrieved from Wordpress: hardi91.wordpress.com

Indonesia, C. (2016, April 16). Kenali Karakter dan Keinginan Pekerja berdasarkan Generasi. Jakarta, Indonesia. 
Meachem, J. (2004). Googleplex: A New Campus Community. Sydney: Clive Wilkinson Architect.

Meachem, J. (2004). Googleplex: A New Campus Community. Sydney: Clive Wilkinson Architect.

Muthahhari, T. (2017, Oktober 30). Benarkah Milenial Tidak Setia kepada Perusahaan? Retrieved from Tirto.id: https://tirto.id/benarkah-milenial-tidak-setia-kepadaperusahaan-czf7

Peta Zonasi dan Tata Ruang Jakarta. (n.d.). Retrieved from Sindikat: http://www.sindikat.co.id/zonasi

Soraya, N. (2018). Jakarta Property Market Report. Jakarta: Colliers International Indonesia.

Suhendra. (2016, Agustus 20). Mengenal Perilaku Tak Setia Milenial. Retrieved from Tirto.id: https://tirto.id/mengenal-perilaku-tak-setia-milenial-bCpy

Wibisono, N. (2016, September 16). Kantor Ideal Bagi Generasi Milenial. Retrieved from Tirto.id: https://tirto.id/kantor-ideal-bagi-generasi-milenial-bKSh

Wibisono, N. (2016, Agustus 20). Memahami Generasi Galau. Retrieved from Tirto.id: https://tirto.id/memahami-generasi-galau-cY 
